\title{
Isolates of Bacillus thuringiensis from Maranhão biomes with potential insecticidal action against Aedes aegypti larvae (Diptera, Culicidae)
}

\author{
J. L. Viana ${ }^{a, b}$ (D), J. Soares-da-Silva ${ }^{\text {(D), M. R. A. Vieira-Neta }}$ (D), W. P. Tadeie (D), \\ C. D. Oliveira ${ }^{\text {(D) , F. C. Abdalla }}$ (D), C. A. Peixoto ${ }^{h}$ (D) and V. C. S. Pinheiro ${ }^{i *}$ (D)
}

aPrograma de Pós-graduação em Biodiversidade e Biotecnologia da Rede BIONORTE - PPG BIONORTE, Universidade do Estado do Amazonas - UEA, Av. Carvalho Leal, 1777, Ed. Anexo, $4^{\circ}$ andar, Cachoeirinha, CEP 69065-00, Manaus, AM, Brasil

bLaboratório de Entomologia Médica, Programa de Pós-graduação em Biodiversidade, Ambiente e Saúde, Centro de Estudos Superiores de Caxias - CESC, Universidade Estadual do Maranhão - UEMA, Praça Duque de Caxias, Morro do Alecrim, s/n, CEP 65604-380, Caxias, MA, Brasil

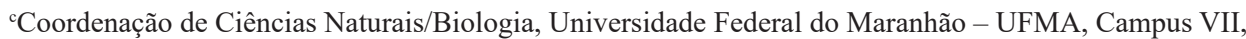
Av. Dr. José Anselmo, 2008, São Sebastião, CEP 65400-000, Codó, MA, Brasil

dUniversidade Federal de São Carlos - UFSCar, Campus Sorocaba, Rodovia João Leme dos Santos, SP-264, Km 110, Itinga, CEP 18052-780, Sorocaba, SP, Brasil

'Programa de Pós-graduação em Entomologia, Laboratório de Malária e Dengue, Instituto Nacional de Pesquisas da Amazônia - INPA, Av. André Araújo, 2936, Petrópolis, CEP 69067-375, Manaus, AM, Brasil

${ }^{\mathrm{f}}$ Grupo Mosquitos Vetores: Endosimbionte e Interação Patógeno Vetor, Centro de Pesquisa René Rachou, Av. Augusto de Lima, 1715, Barro Preto, CEP 30190-002, Belo Horizonte, MG, Brasil

${ }^{g}$ Laboratório de Biologia Estrutural e Funcional - LABEF, Universidade Federal de São Carlos - UFSCar, Campus Sorocaba, Rodovia João Leme dos Santos, SP-264, Itinga, CEP 18052-780, Sorocaba, SP, Brasil

hLaboratório de Ultraestrutura, Instituto de Pesquisas Aggeu Magalhães, Fundação Oswaldo Cruz - FIOCRUZ, Av. Moraes Rego, s/n, Campus UFPE, Cidade Universitária, CEP 50740-465, Recife, PE, Brasil

'Laboratório de Entomologia Médica, Departamento de Química e Biologia, Centro de Estudos Superiores de Caxias - CESC, Universidade Estadual do Maranhão - UEMA, Praça Duque de Caxias, s/n, Morro do Alecrim, CEP 65604-380, Caxias, MA, Brasil

*e-mail: pinheirovcs@gmail.com

Received: May 2, 2019 - Accepted: October 23, 2019 - Distributed: February 28, 2021

(With 5 figures)

\begin{abstract}
Entomopathogenic agents are viable and effective options due to their selective action against insects but benign effects on humans and the environment. The most promising entomopathogens include subspecies of Bacillus thuringiensis (Bt), which are widely used for the biological control of insects, including mosquito vectors of human pathogens. The efficacy of $B$. thuringiensis toxicity has led to the search for new potentially toxic isolates in different regions of the world. Therefore, soil samples from the Amazon, Cerrado and Caatinga biomes of the state of Maranhão were evaluated for their potential larvicidal action against Aedes aegypti. The isolates with high toxicity to mosquito larvae, as detected by bioassays, were subjected to histological evaluation under a light microscope to identify the genes potentially responsible for the toxicity. Additionally, the toxic effects of these isolates on the intestinal epithelium were assessed. In the new B. thuringiensis isolates toxic to A. aegypti larvae, cry and cyt genes were amplified at different frequencies, with cry 4, cyt1, cry32, cry 10 and cry 11 being the most frequent (33-55\%) among those investigated. These genes encode specific proteins toxic to dipterans and may explain the severe morphological changes in the intestine of $A$. aegypti larvae caused by the toxins of the isolates.
\end{abstract}

Keywords: mosquito vectors, entomopathogenic bacterium, cry and cyt genes, histology.

\section{Isolados de Bacillus thuringiensis de biomas maranhenses com potencial ação inseticida contra larvas de Aedes aegypti (Diptera, Culicidae)}

\section{Resumo}

Os agentes entomopatógenos são alternativas viáveis e eficazes, devido à sua ação seletiva para insetos sendo inofensivos ao homem e ao meio ambiente. Dentre os entomopatógenos mais promissores, destacam-se as subespécies de Bacillus thuringiensis (Bt) amplamente utilizadas no controle biológico de insetos incluindo espécies de mosquitos vetores de 
agentes patogênicos ao homem. A eficiência da toxicidade de Bt incentiva a prospecção de novos isolados em diversas regiões do mundo. Desta forma, em busca de novos isolados de B. thuringiensis potencialmente tóxicos, amostras de solo provenientes dos biomas Amazônia, Cerrado e Caatinga do estado do Maranhão foram avaliadas em relação ao seu potencial larvicida para Aedes aegypti. Os isolados que provocaram elevada toxicidade para larvas do mosquito, detectada por bioensaios, foram avaliados em relação aos potenciais genes responsáveis pela atividade tóxica, além da avaliação de efeitos tóxicos no epitélio intestinal através de análises histológicas em microscopia de luz. Os novos isolados de Bt tóxicos para larva de $A$. aegypti amplificaram frequências diferentes de genes cry e cyt sendo os mais frequentes (55-33\%) os cry4, cyt1, cry32, cry10 e cryl1 dentre os investigados. Esses genes codificam para proteínas tóxicas específicas para ordem Diptera, e podem explicar as severas alterações morfológicas provocadas pelas toxinas dos isolados observadas no intestino das larvas de A. aegypti.

Palavras-chave: insetos vetores, bacilos entomopatogênicos, genes cry e cyt, histopatologia.

\section{Introduction}

Aedes (Stegomyia) aegypti (L. 1762) is an important vector of the viruses that cause dengue fever, urban yellow fever, chikungunya and Zika fever. This mosquito is anthropophilic and domestic, with diurnal haematophagic activity (Consoli and Lourenço-de-Oliveira, 1994; Vasconcelos, 2015; Valle et al., 2016; Montagner et al., 2018), and its adaptive success is associated with favourable domestic or peridomestic conditions, such as the presence of humans and aquatic breeding sites; rapid development and eggs that are resistant to desiccation (Zara et al., 2016; Carvalho and Moreira, 2017; Bassani et al., 2019). These factors contribute to the difficulty in controlling this mosquito and thus to a global public health problem.

Currently, the $A$. aegypti mosquito is controlled by eliminating breeding sites or using chemical insecticides to target adults and/or larvae (Braga and Valle, 2007; Brasil, 2019). However, the frequent use of chemical insecticides selects for resistant mosquito populations, limiting the effectiveness of this strategy in shrinking the $A$. aegypti population. Therefore, it is necessary to search for alternative methods of reducing the population size of this vector, such as the use of entomopathogenic bacteria (Carvalho and Moreira, 2017; Moyes et al., 2017; Aponte et al., 2019).

The entomopathogenic bacterium Bacillus thuringiensis (Bt), Goldberg and Margalit (1977) is considered highly effective at controlling immature forms of mosquitoes since several isolates produce $\delta$-endotoxin-containing protein crystals with insecticidal action against several insect orders, including Diptera (Van Frankenhuyzen, 2013; Soares-da-Silva et al., 2017; Soberón et al., 2018). Bacillus thuringiensis subsp. kurstaki/B. thuringiensis subsp. aizawai (Lepidoptera), B. thuringiensis subsp. tenebrionis (Coleoptera) and B. thuringiensis subsp. israelensis (Diptera) are examples of subspecies with specific action against different groups of insects (Seifinejad et al., 2008).

The success of this bacterium in biological control is due to its wide insecticidal spectrum as well as the susceptibility of the target insect to the bacillus, which causes effective larval toxicity. The onset of larval toxicity occurs immediately after ingestion of the bacterial crystals, which are later solubilized at the alkaline $\mathrm{pH}$ in the larval midgut, releasing the protoxins. These protoxins are processed into a toxic form by serine proteases, and in this active form, the toxins bind to the specific receptors of the intestinal epithelium. This binding enables the formation of pores in the cell membrane, causing an ion imbalance that consequently causes cell rupture and disintegration and culminates in the death of the insect (Glare and O'Callagham, 2000; Zhang et al., 2017; Soberón et al., 2018).

Isolates of $\mathrm{Bt}$ with action against Diptera produce crystals with $\delta$-endotoxins from the Cry and Cyt families that are encoded by the cry and cyt genes during sporulation (Schnepf et al., 1998), and these toxins can act synergistically in larval toxicity (Crickmore et al., 1995; Ben-Dov, 2014). As described above, B. thuringiensis subsp. israelensis has insecticidal activity against the larvae of different mosquito species; thus, it is used worldwide to manufacture insecticidal formulations for vector control (Raymond et al., 2010; Bravo et al., 2011). Due to the combination of cry and cyt genes, the toxic activity of this subspecies can cause larval death $24 \mathrm{~h}$ after of exposure (Sun et al., 2013; El-Kersh et al., 2014; Soares-da-Silva et al., 2017).

The presence of cry and cyt genes can be used to predict the insecticidal activity of a novel isolate. Due to the complexity of the action of $\delta$-endotoxins, it is also necessary to assess the frequency of the genes involved in larval mortality and to understand the mode of action of these proteins in larval intestinal cells (Cavados et al., 2004; Oliveira et al., 2009; Soberón et al., 2018).

Information on the toxic effects of this important bacterium may aid in the selection of new isolates for use in the field control of mosquito disease vectors, such as $A$. aegypti. The toxicity of each Bt isolate must also be assessed through in vivo assays based on the ability of the bacteria to interact with the intestinal epithelium of the susceptible host.

Thus, the present research investigated the presence of genes encoding mosquito-acting insecticidal proteins and compared the epithelial damage due to different toxin combinations with that caused by the standard Bti strain. Assessing the ability of different combinations of Cry and Cyt toxins to interact with the intestinal epithelium of susceptible hosts will allow new isolates for the control of mosquito transmitters of pathogens, such as A. aegypti, to be selected. 


\section{Material and Methods}

\subsection{Selection of Bacillus thuringiensis isolates}

A total of nine Bt isolates that showed high toxicity to A. aegypti larvae, as previously determined in susceptibility bioassays (Lobo et al., 2018), were selected. The gene profiles of these isolates differed from those of the strains that are already used to control mosquitoes, such as B. thuringiensis subsp. israelensis (cry4Aa, cry4Ba, cry10Aa, cry $11 \mathrm{Aa}$ and $\mathrm{cry} 11 \mathrm{Ba}$ ), according to Soares-da-Silva et al. (2017). The purpose of this study was to characterize isolates with new combinations of cry and cyt genes that are effective in the control of $A$. aegypti for future use in rotation with existing strains. The Bt isolates used in the present study were obtained from the Banco de Bacilos Entomopatogênicos do Maranhão (BBENMA) (Table 1).

\subsection{DNA extraction from Bacillus thuringiensis isolates}

To obtain DNA from the bacteria, colonies of the new $\mathrm{Bt}$ isolates were grown in Petri dishes containing nutrient agar (Kasvi) for $18 \mathrm{~h}$ at $28{ }^{\circ} \mathrm{C}$. A colony of each isolate was resuspended in $1 \mathrm{~mL}$ of sterile water in microtubes
$(1.5 \mathrm{~mL})$ that were then centrifuged for $1 \mathrm{~min}$ at $17,226 \mathrm{~g}$ and $25^{\circ} \mathrm{C}$. After centrifugation, the supernatant was discarded, and $100 \mu \mathrm{L}$ of InstaGene ${ }^{\mathrm{TM}}$ Matrix (Bio-Rad) was added. The samples were subjected to two incubations and shaking in a vortex mixer (Vision Scientific): the first at $56^{\circ} \mathrm{C}$ for $25 \mathrm{~min}$ with shaking for $10 \mathrm{sec}$ and the second at $100^{\circ} \mathrm{C}$ for $8 \mathrm{~min}$ with shaking for $10 \mathrm{sec}$. Finally, centrifugation was performed at $17,226 \mathrm{~g}$ for $2.5 \mathrm{~min}$ and $25^{\circ} \mathrm{C}$. Aliquots of the supernatant $(100 \mu \mathrm{L})$ were collected from the samples and transferred to sterile microtubes to evaluate the quantity and quality of the DNA by using an L-Quant spectrophotometer (Loccus). DNA samples were stored at $-18^{\circ} \mathrm{C}$ for later use.

\subsection{PCR for amplification of Dipteran-specific Bacillus thuringiensis genes}

In this study, the isolates BtMA-401, BtMA-755 and BtMA-761 were characterized by polymerase chain reaction (PCR) with general primers to identify the families of genes encoding the mosquitocidal toxins: cryl, cry4, cry 10, cry 11, cry32, cry24, cy44Aa, cyt1 and cyt2 (Table 2).

Table 1. Bacillus thuringiensis isolates collected in biomes State of Maranhão with larvicida activity in Aedes aegypti.

\begin{tabular}{|c|c|c|c|c|}
\hline Isolates & Biome & Substrate & Municipality/MA & Latitude (S) Longitude (W) \\
\hline BtMA-1791 & Amazônia & Solo & Santa Luzia & 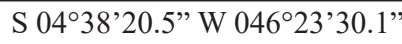 \\
\hline BtMA-2291 & Amazônia & Solo & Santa Inês & S $03^{\circ} 85^{\prime} 73.3^{\prime \prime} \mathrm{W} 045^{\circ} 53^{\prime} 49.2^{\prime \prime}$ \\
\hline BtMA-237 & Amazônia & Solo & Santa Inês & S $03^{\circ} 85^{\prime} 73.3^{\prime \prime} \mathrm{W} 045^{\circ} 53^{\prime} 49.2^{\prime \prime}$ \\
\hline BtMA- $401^{2}$ & Cerrado & Solo & Colinas & $\mathrm{S} 06^{\circ} 04^{\prime} 53.5^{\prime \prime} \mathrm{W} 044^{\circ} 23^{\prime} 10.6^{\prime \prime}$ \\
\hline BtMA-459 & Cerrado & Solo & São J. dos Patos & $\mathrm{S} 06^{\circ} 50^{\prime} 37.5^{\prime \prime} \mathrm{W} 043^{\circ} 68^{\prime} 65.8^{\prime \prime}$ \\
\hline BtMA-5591 & Cerrado & Solo & Balsas & S 0753'53.3" W 046º3'91.1" \\
\hline BtMA- $686^{1}$ & Cerrado & Solo & Duque Barcelar & $\mathrm{S} 04^{\circ} 13^{\prime} 72.5^{\prime \prime} \mathrm{W} 042^{\circ} 94^{\prime} 91.8^{\prime \prime}$ \\
\hline BtMA- $755^{3}$ & Amazônia & Solo & São J. de Ribamar & S $02^{\circ} 27^{\prime} 56.5^{\prime \prime} \mathrm{W} 044^{\circ} 11^{\prime} 43.2^{\prime \prime}$ \\
\hline BtMA-7613 & Amazônia & Solo & São J. de Ribamar & $\mathrm{S} 02^{\circ} 27^{\prime} 56.5^{\prime \prime} \mathrm{W} 044^{\circ} 11^{\prime} 43.2^{\prime \prime}$ \\
\hline
\end{tabular}

${ }^{1}$ Soares-da-Silva et al. (2017); ${ }^{2}$ Lobo et al. (2018); ${ }^{3}$ Banco de Bacilos Entomopatogênicos do Maranhão (BBENMA).

Table 2. Lists of genes and primers used for gene amplification cry e cyt of Bacillus thuringiensis in PCR.

\begin{tabular}{|c|c|c|c|c|}
\hline Genes & Sequence 5'-3' & Product size & $\mathrm{TM}\left({ }^{\circ} \mathrm{C}\right)$ & Reference \\
\hline cryl & $\begin{array}{l}\text { F - CTGGATTTACAGGTGGGGATAT } \\
\text { R - TGAGTCGCTTCGCATATTTGACT }\end{array}$ & $543-594$ & 52 & Bravo et al. (1998) \\
\hline cry 4 & $\begin{array}{l}\text { F - GCATATGATGTAGCGAAACAAGCC } \\
\text { R - GCGTGACATACCCATTTCCAGGTC }\end{array}$ & $439-459$ & 50 & Jouzani et al. (2008) \\
\hline cry 10 & $\begin{array}{l}\text { F - TCAATGCTCCATCCAATG } \\
\text { R - CTTGTATAGGCCTTCCTCCG }\end{array}$ & $\sim 348$ & 51 & Jouzani et al. (2008) \\
\hline cryll & $\begin{array}{l}\text { F - TTAGAAGATACGCCAGATCAAGC } \\
\text { R - CATTTGTACTTGAAGTTGTAATCCC }\end{array}$ & $\sim 305$ & 51 & Bravo et al. (1998) \\
\hline cry 24 & $\begin{array}{l}\text { F - TTATCAATGTTAAGGGATGC } \\
\text { R - ACTGGATCTGTGTATATTTTCCTAG }\end{array}$ & $\sim 304$ & 52 & Ibarra et al. (2003) \\
\hline cry 32 & $\begin{array}{l}\text { F - TGGTCGGGAGAGAATGGATGGA } \\
\text { R - ATGTTTGCGACACCATTTTC }\end{array}$ & $676-677$ & 48 & Ibarra et al. (2003) \\
\hline cry $44 A a$ & $\begin{array}{l}\text { F - CATTACACGGGGTGCGTTAT } \\
\text { R - CCGCACTTACATGTGTCCAA }\end{array}$ & $\sim 444$ & 60 & Vidal-Quist et al. (2009) \\
\hline cyt1 & $\begin{array}{l}\text { F - CCTCAATCAACAGCAAGGGTTATT } \\
\text { R -TGCAAACAGGACATTGTATGTGTAATT }\end{array}$ & $477-480$ & 52 & Ibarra et al. (2003) \\
\hline cyt 2 & $\begin{array}{l}\text { F - ATTACAAATTGCAAATGGTATTCC } \\
\text { R -TTTCAACATCCACAGTAATTTCAAATGC }\end{array}$ & $355-356$ & 56 & Ibarra et al. (2003) \\
\hline
\end{tabular}


The other isolates were previously characterized by Soares-da-Silva et al. (2017). The following DNA samples from Bt subspecies were used as positive controls in the reactions: B. thuringiensis subsp. azawai-Bta Xentari ${ }^{\circledR}$ WDG (cry1), B. thuringiensis subsp. israelensis-Bti T14 001 and BtMA-750 (cry4, cry10, cry11, cyt1 and cyt2), B. thuringiensis subsp. sotto-T03 001 (cry24), B. thuringiensis subsp. yunnanensis-Bty T20 001 (cry32) and B. thuringiensis subsp. entomocidus-T06a001 (cry44Aa).

The PCRs were performed using the following reagents: $2.5 \mu \mathrm{L}$ of $\mathrm{GoTaq}^{\circledR}$ Flexi DNA polymerase buffer, $2.5 \mu \mathrm{L}$ of dNTPs, $0.5 \mu \mathrm{L}$ of $\mathrm{MgCl} 2,0.5 \mu \mathrm{L}$ of each primer, $0.1 \mu \mathrm{L}$ of GoTaq ${ }^{\circledR}$ DNA polymerase (Promega) at approximately $50 \mathrm{ng} / \mu \mathrm{L}$ and enough water (Milli-Q, Millipore) to reach a final volume of $12.5 \mu \mathrm{L}$. Amplifications were performed in a Gencycler-G96G thermocycler (Biosystems) with the following program: an initial denaturation step at $94{ }^{\circ} \mathrm{C}$ for $5 \mathrm{~min}$, followed by 35 denaturation cycles at $94^{\circ} \mathrm{C}$ for 1 min, annealing $\left(\right.$ cry $32-48{ }^{\circ} \mathrm{C} ;$ cry $4-50{ }^{\circ} \mathrm{C}$; cry 10 and cry $11-51{ }^{\circ} \mathrm{C}$; cry 1, cry 24 and $c y t 1-52{ }^{\circ} \mathrm{C}$; cyt $2-56{ }^{\circ} \mathrm{C}$; cry $44 \mathrm{Aa}-60^{\circ} \mathrm{C}$ ), extension at $72^{\circ} \mathrm{C}$ for $1 \mathrm{~min}$ and a final extension step at $72{ }^{\circ} \mathrm{C}$ for $7 \mathrm{~min}$.

The amplified products were stained with a mix of $2 \mathrm{X}$ Blue/Orange Loading Dye (Promega), loading buffer and 1X GelRed Nucleic Acid Gel Stain (Biotium) dye and were electrophoretically separated on $1 \%$ agarose gels. The sizes of the generated fragments were compared to the DNA Ladder $^{\circledR} 1-\mathrm{Kb}$ molecular weight marker (Promega), and the electrophoresis gels were visualized using the L-PIX TOUCH imaging system (Loccus Biotechnology).

\subsection{Histological analysis}

The morphological changes in intestinal epithelial cells of $A$. aegypti larvae caused by $\mathrm{Bt}$ isolates were evaluated according to Oliveira et al. (2009), with modifications. The assays were performed using groups of 10 third-instar larvae from a colony kept at an average temperature of $26 \pm 2{ }^{\circ} \mathrm{C}$, a relative humidity of $85 \%$ and a photophase of $12 \mathrm{~h}$ in the Medical Entomology Laboratory. The larvae were treated with $5 \mathrm{mg} / \mathrm{L}$ crystal/spore suspensions obtained from sporulated cultures of each bacillus isolate in containers $(50 \mathrm{~mL})$ holding $10 \mathrm{~mL}$ of distilled water. A replicate treated with $B$. thuringiensis subsp. israelensis T14 001 was used as a positive control. The bioassays were performed in triplicate and maintained at $26 \pm 2{ }^{\circ} \mathrm{C}$ and a relative humidity of $80 \%$.

Morphological changes in the larval intestine were examined $6 \mathrm{~h}$ and $24 \mathrm{~h}$ after exposure to the bacterial solution. At each time point, live larvae were collected individually using Pasteur pipettes, placed in sterile microtubes $(1.5 \mathrm{~mL})$ containing $4 \%$ paraformaldehyde fixative and stored at room temperature. For histological analysis, mainly live larvae were used, with the exception of strains that showed $100 \%$ mortality in $24 \mathrm{~h}$.

The material was first incubated in $70 \%$ alcohol and maintained in an automatic tissue processor for histological examinations (OMA DM40) for $8 \mathrm{~h}$. The samples were then serially dehydrated in ethanol (from $70 \%$ to $100 \%$ ), cleared in xylol and embedded in paraffin at $56-58{ }^{\circ} \mathrm{C}$ (Leica $E G$ 1120). Histological sections (4 mm) were obtained using a microtome (Zeiss HYRAX M55) stained with haematoxylin and eosin (HE) and mounted with Entellan. The samples were observed and analysed under a light microscope at magnifications of $40 \mathrm{X}$ and $100 \mathrm{X}$ (Leica LAS EZ).

\section{Results}

\subsection{Gene profile of Bacillus thuringiensis isolates}

The investigated cry and $c y t$ genes were detected in all of the new Bt isolates, some of which showed amplification of a single gene, while others showed a combination of two or more genes (Table 3 and Figure 1). The cry 24 and cry $44 A$ a genes, characteristic of $B$. thuringiensis subs. sotto and $B$. thuringiensis subs. entomocidus, respectively, were not identified in any of the evaluated Bt isolates (Table 3 ).

The most frequent genes were cry 32 and $c y t 1$, which were present in $56 \%$ of the new Bt isolates, followed by the cry 11 and cyt 2 genes (44\%) and the cry 4 gene (33\%). The cryl and cry 10 genes were the least frequent, with each found in only a single isolate: BtMA-459 and BtMA-755, respectively (Table 3 and Figure 2).

Among the isolates investigated, the isolate with the most genes was BtMA-459, with the amplification of five genes: three cry genes (cryl, cry4 and cry32) and two cyt genes (cyt 1 and cry 2). The isolates BtMA-401 and BtMA-559 each harboured only one gene (cry32 and cry11, respectively), while the others showed combinations of two or more toxic genes (Table 3 and Figure 1).

Table 3. Bacillus thuringiensis isolates and cry and cyt genes detected in PCR assays.

\begin{tabular}{|c|c|}
\hline Isolates & Genes \\
\hline Bta* & cryl 1 \\
\hline Bti* & cry 4, cry 10, cry 11, cyt 1 and $c y t 2$ \\
\hline Bt sotto* & $\operatorname{cry} 24$ \\
\hline Bty* & cry32 \\
\hline Bt entomocidus* & $\operatorname{cry} 44 A a$ \\
\hline BtMA-750 & cry 4, cry 10, cry 11, cyt 1 and cyt 2 \\
\hline BtMA-179' & cr 4, cry 11 and cyt 1 \\
\hline BtMA-2291 & cy4, cry 11 and cyt 2 \\
\hline BtMA-237' & cry 32 and cyt 1 \\
\hline BtMA-4012 & cry32 \\
\hline BtMA-459' & cryl, cry 4, cry 32, cyt 1 and cyt 2 \\
\hline BtMA-559 & cryll \\
\hline BtMA- $686^{1}$ & cry 11 and cyt2 \\
\hline BtMA- $755^{3}$ & cry 10, cry 32, cyt 1 and cyt 2 \\
\hline BtMA-7613 & cry 32 and cyt 1 \\
\hline
\end{tabular}

Legend: positive controls. ${ }^{*} \mathrm{Bta}=$ Bacillus thuringiensis subsp. Aizawai; Bti = Bacillus thuringiensis subsp. israelensis; Bt sotto $=B$. thuringiensis subsp. sotto; Bty $=$ Bacillus thuringiensis subsp. yunnanensis; $\mathrm{Bt}$ entomocidus $=B$. thuringiensis subsp. entomocidus; BtMA = Bacillus thuringiensis of Maranhão. ${ }^{1}$ Soares-da-Silva et al. (2017); ${ }^{2}$ Lobo et al. (2018); ${ }^{3}$ Banco de Bacilos Entomopatogênicos do Maranhão. 


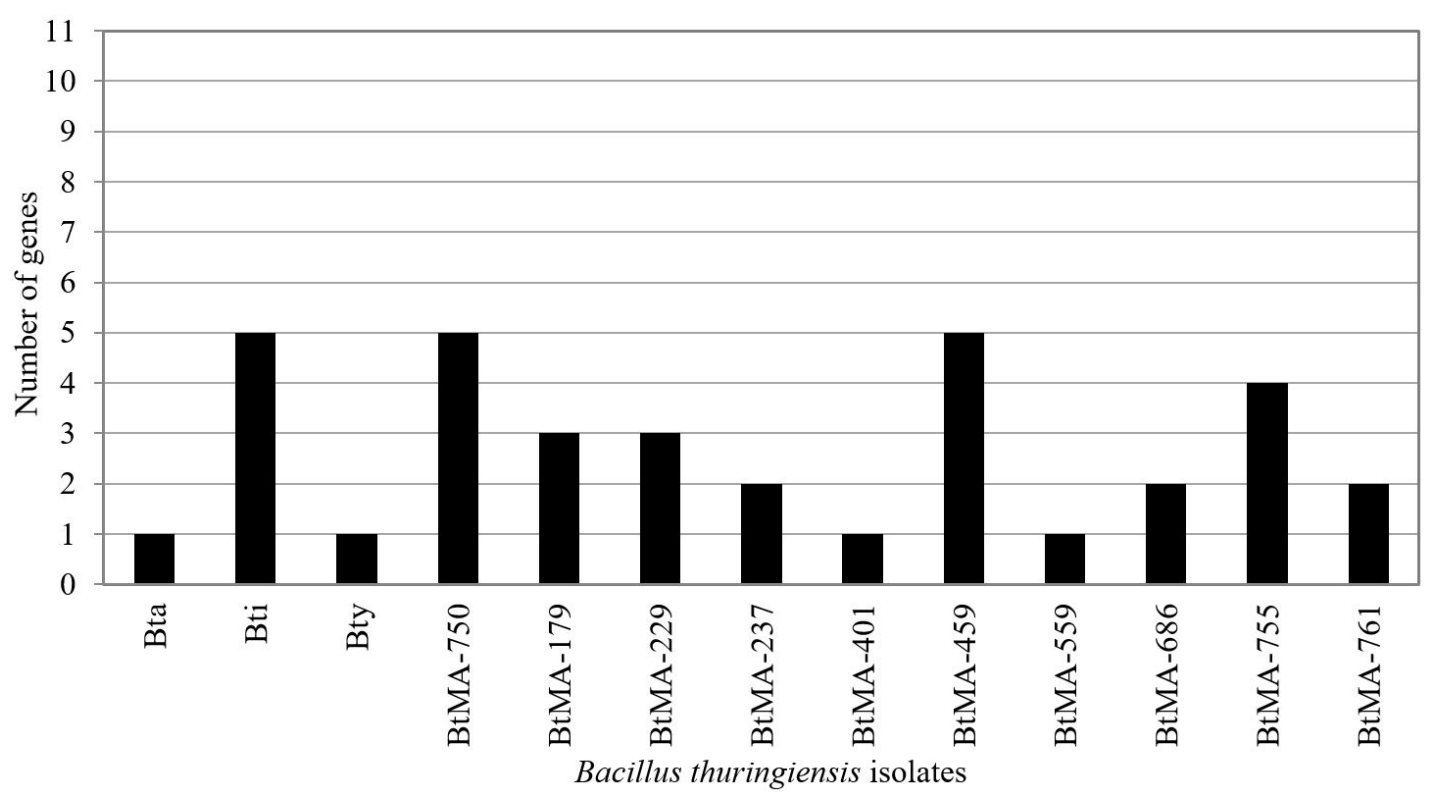

Figure 1. Genes profiles the 10 new isolates of Bt from Maranhão. Legend: Bacillus thuringiensis subsp. aizawai (Bta), Bacillus thuringiensis subsp. israelensis T14001 (Bti), Bacillus thuringiensis subsp. Bacillus thuringiensis subsp. yunnanensis (Bty) and BtMA Bacillus thuringiensis of Maranhão.

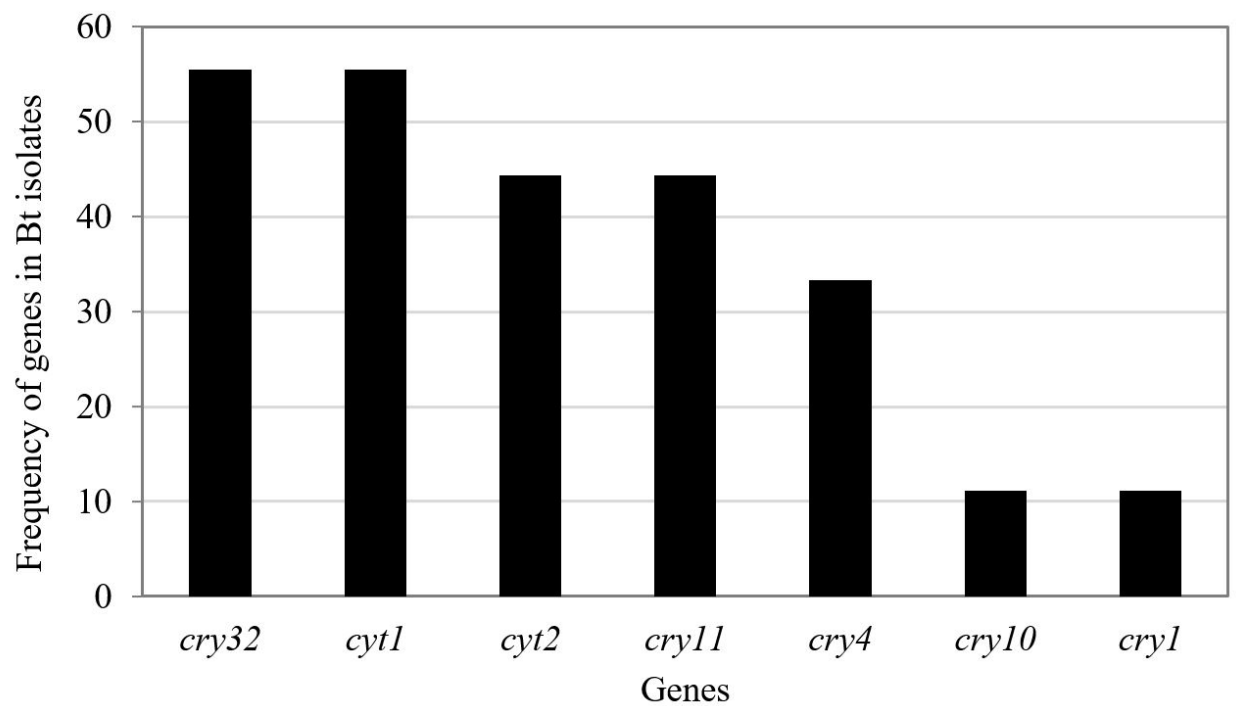

Figure 2. Frequency of the cry and cyt genes present in the new 10 isolates of Bt from Maranhão.

\subsection{Alterations in the intestinal epithelium of Aedes aegypti larvae}

The nine $B$. thuringiensis isolates evaluated in this study were toxic to $A$. aegypti larvae and caused cytopathologic damage to the intestinal epithelium after treatment with $5 \mathrm{mg} / \mathrm{L}$ crystal/spore suspensions. This result was similar to that observed for the positive control, in which the larvae treated with $B$. thuringiensis subsp. israelensis presented significant damage to intestinal cells. After this exposure period, the larvae presented structural disorganization of the epithelium, extravasation of the vesicles in the space between the lumen and the epithelium and the presence of digestive vacuoles (Figure 3).

The larvae treated with the $\mathrm{Bt}$ isolates displayed a series of toxic effects on the epithelium after $6 \mathrm{~h}$ of exposure to the isolates. The microvilli of the intestinal cells of the larvae treated with Bt were irregular and partially destroyed (Figure 4F), and dissociation of the intestinal cells (Figure 4A, B, F, G and H) and evidence of cell degeneration were observed (Figure 4C, D, E and I). 


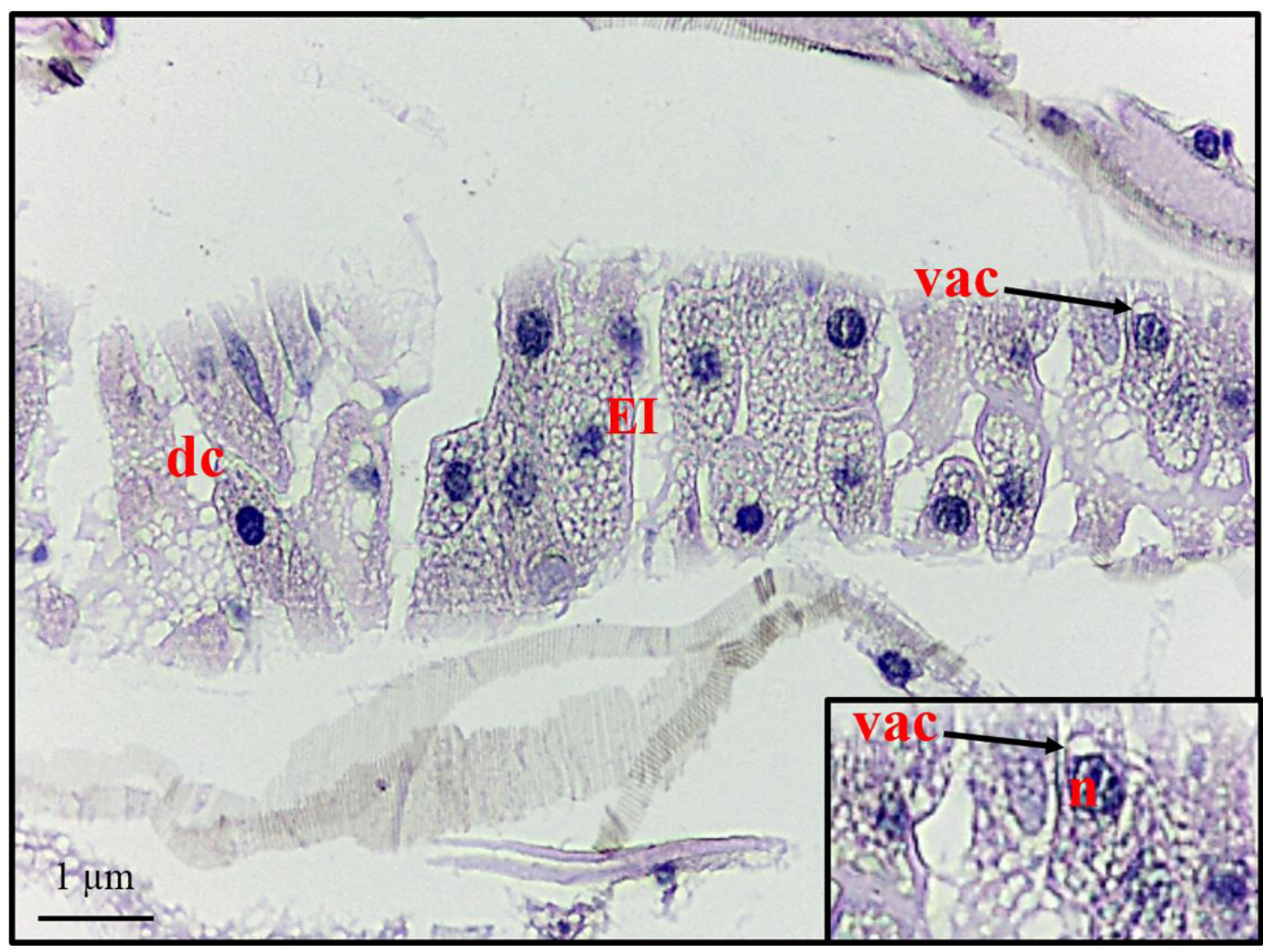

Figure 3. Intestinal cells of larvae of third instar of Aedes aegypti. Positive control: after 6h of exposure to the of Bacillus thuringiensis subsp. israelensis. $\mathrm{EI}=$ intestinal epithelium; $\mathrm{n}=$ nucleus; vac = vacuole; $\mathrm{dc}=$ degenerated cells.

Intense production of digestive intestinal vesicles was also observed in the larvae after $6 \mathrm{~h}$ of action of BtMA-179 (Figure 4A), in addition to a large number of intestinal cells with large vacuoles (Figure $4 \mathrm{H}$ ).

The damage caused by new isolates was much greater after $24 \mathrm{~h}$ of exposure to $5 \mathrm{mg} / \mathrm{L}$ crystal/spore suspensions, causing the death of the treated larvae. The larvae exposed to isolates BtMA-237, (B) BtMA-229, (C) BtMA-459, and (D) BtMA-179 showed disorganized, loose and disrupted intestinal cells with the presence of digestive vesicles trapped in the space between the lumen and epithelial cells (Figure 5A and B). At this point in the evaluation, the microvilli of the cells were completely destroyed (Figure 5C and D).

\section{Discussion}

Different profiles of toxic cry and cyt genes were detected among the evaluated $\mathrm{Bt}$ isolates, with a minimum of one and a maximum of five of the nine classes of the analysed genes. This diversity of profiles could be attributed to the high frequency of genetic information exchange between Bt bacteria, enabling variation in the genes within a single isolate (Bravo et al., 1998).

These new bacterial gene combinations can give rise to isolates with gene compositions specific to different groups of insects, and such a broad spectrum of action against different groups may be the reason why $\mathrm{Bt}$ is successful in insect control (Ben-Dov et al., 1997; Ben-Dov, 2014; Bravo et al., 2011). In addition, the genetic diversity of the new Bt isolates between the two biomes where they were collected (Amazonia and Cerrado) corroborated the results of other studies (Baig and Mehnaz, 2010; Mahalakshmi et al., 2012; Shishir et al., 2014) that showed genetic diversity in cry and cyt toxins between samples of isolates collected from different ecosystems. None of the Bt isolates harboured all of the investigated cry and $c y t$ genes, but this result is perhaps expected since none of the known Bt species or subspecies presents all of the potential genes. However, it should be emphasized that some isolates may present high toxicity to susceptible insects even with a synthetic composition of cry-cyt genes (Costa et al., 2010).

The number of genes in a single isolate does not appear to be the factor determining the immediate death of the susceptible insect per se, but it may affect the toxic activity of bacteria when they encounter optimal conditions in the gut of the insect. This is exemplified by comparing the BtMA-401 and BtMA-559 isolates, each of which contained a single gene, and the BtMA-459 isolate, in which 5 genes were amplified, as all of these 


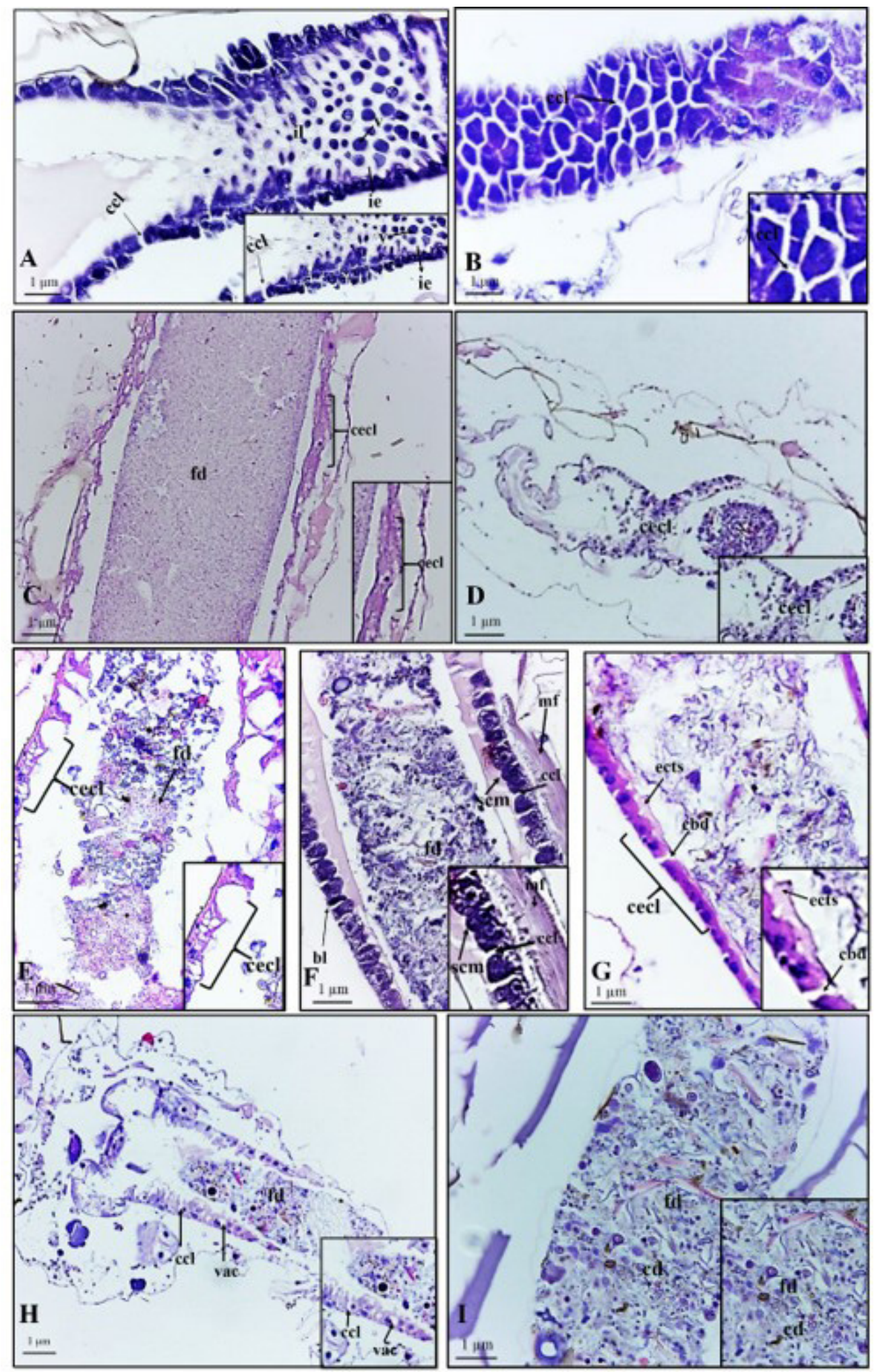

Figure 4. Intestinal cells of larvae of third instar Aedes aegypti after $6 \mathrm{~h}$ of exposure to the new isolates of Bacillus thuringiensis. Legend: (A) BtMA-179; (B) BtMA-237; (C) BtMA-401; (D) BtMA-459; (E) BtMA-750; (F) BtMA-686; (G) BtMA-559; (H) BtMA-755; (I) BtMA-229. il = intestinal lumen; ie = intestinal epithelium; ects = ectoperitrophic space; $\mathrm{mf}=$ muscular fibers; $\mathrm{bl}=$ basal lamin; $\mathrm{ccl}=$ cell clearance; $\mathrm{v}=$ vesicle; $\mathrm{fd}=$ food; $\mathrm{cecl}=$ cell clutter; $\mathrm{cd}=$ cell degeneration; $\mathrm{cbd}=$ cell breakdown; $\mathrm{scm}=$ smooth cells without microvilli; vac $=$ vacuole inside the cell around the nucleus. 

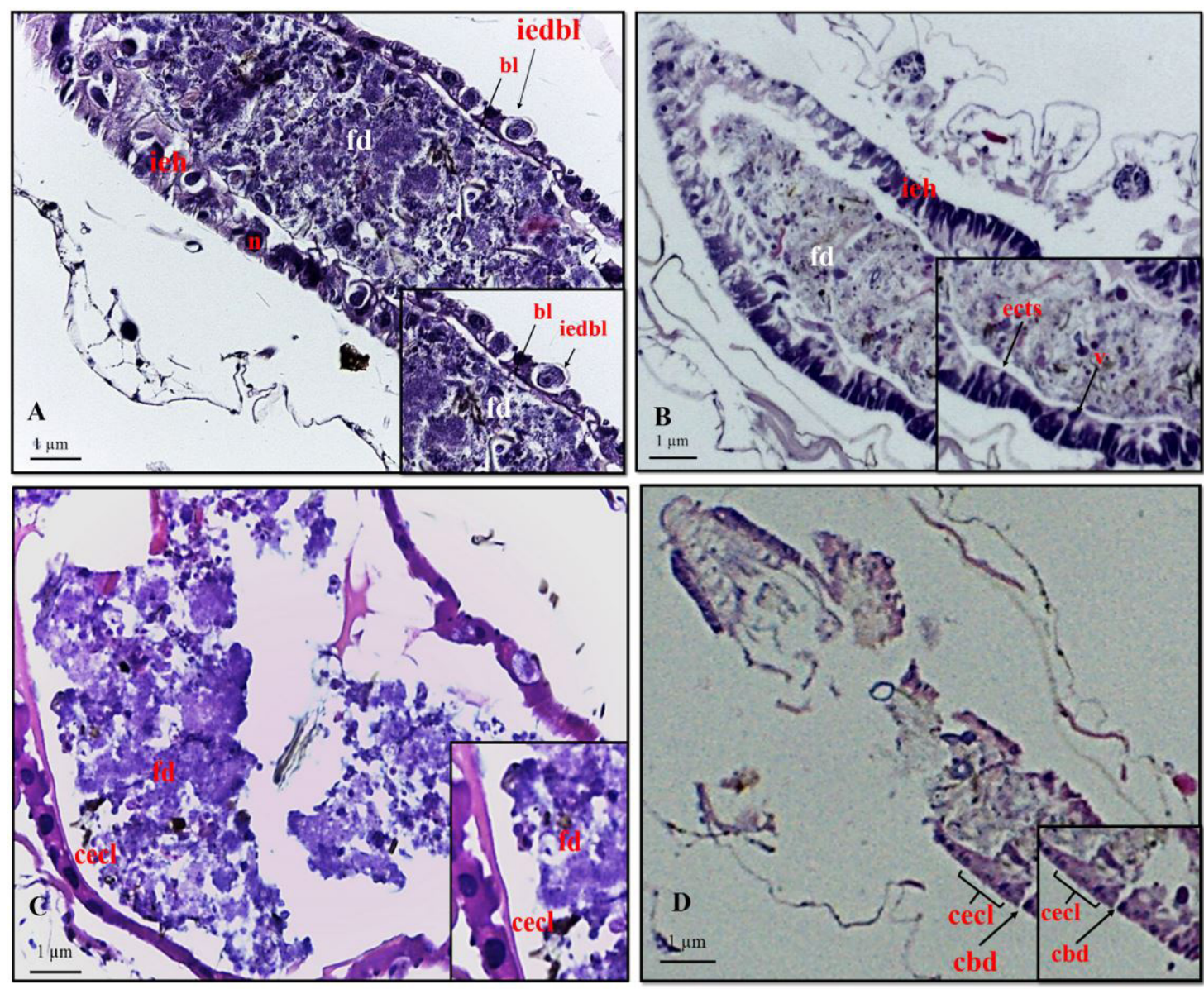

Figure 5. Intestinal cells of the larvae of the third stage Aedes aegypti after 24 hours of the toxic action of the new isolates of Bacillus thuringiensis. (A) BtMA-237; (B) BtMA-229; (C) BtMA-459; (D) BtMA-179. ieh = intestinal epithelium of hidgut; $\mathrm{bl}=$ basal lamin; ects = ectoperitrophic space; $\mathrm{n}=$ epitelial cell nucleus; $\mathrm{fd}=$ food; iedbl = intestinal epithelial cells detaching from basal lamin; $\mathrm{v}=$ vesicle; cecl = cell clutter; $\mathrm{cbd}=$ cell breakdown.

isolates caused severe damage to the intestinal epithelium of A. aegypti larvae and led to larval death after $6 \mathrm{~h}$ of toxic activity. These results were similar to those observed for Bti T14001 and BtMA-750, which contain seven and five genes that are toxic to mosquito larvae, respectively (Rey et al., 1998; Cavados et al., 2004; Soares-da-Silva et al., 2017). BtMA-401, despite harbouring only one gene, did not present the standard genes found in mosquito-acting strains when analysed for its protein content by the sodium dodecyl sulphate-polyacrylamide-based discontinuous gel (SDS-PAGE) method, showing a profile similar to that of Bti, which was verified by Lobo et al. (2018). There are a large number of proteins within the Cry and Cyt families, many of which have similar sizes, which may explain the similar protein profiles among Bt isolates.

The specificity of, quantity of and synergy between the toxic genes in each isolate, together with the susceptibility of the larvae and the highly alkaline $\mathrm{pH}$ of the intestine, which favours the solubilization and release of protein crystals (Habib, 1983; Boonserm et al., 2005; Lacey, 2007), are important factors determining the effectiveness of bacterial toxicity against larvae. The quantity of genes in Bt isolates was also analysed by other authors, such as Ejiofor and Johnson (2002), Baig and Mehnaz (2010), Khojand et al. (2013) and Soares-da-Silva et al. (2015), who reported the lack of a correlation between the number of amplified genes and the intensity of the toxic activity in the mosquito gut.

The lack of amplification of the cry 24 and cry $44 A a$ genes in all of the Bt isolates can be explained by the different frequencies of Diptera-specific cry genes in native $\mathrm{Bt}$ isolates (Jouzani et al., 2017). Although these genes show specific action against mosquitoes, they are uncommon in new isolates with activity against mosquitoes (Ejiofor and Johnson, 2002; Soares-da-Silva et al., 2017).

The $\delta$-endotoxins are classified into two families of proteins, namely, Cry and Cyt, that can frequently be produced by Bt subspecies. The combination of Cry and Cyt in the same subspecies is frequent in strains with action against Diptera. The Cry family of proteins comprises 74 types that are encoded by 770 different cry genes, whereas the Cyt family is grouped into three types that 
are encoded by 38 cyt genes (Crickmore, 2017). Among the nine genes evaluated in this study, including seven in the cry family $(1,4,10,11,24,32$ and 44) and two in the cyt family (1 and 2), the most frequent were cry $4, c r y 11$, cry 32, cyt 1 and cyt 2 , which were expressed in $33 \%$ to $56 \%$ of the new Bt isolates. This result corroborates those of other studies (Khojand et al., 2013; El-Kersh et al., 2014) and is important since these genes identified in the new $\mathrm{Bt}$ isolates are toxic only to dipterans and can potentially act in synergy (Nazarian et al., 2009; Jouzani et al., 2017; Soares-da-Silva et al., 2017; Lobo et al., 2018) to enable the high activity observed against $A$. aegypti larvae.

The cryl and cryl0 genes were less frequent, which was consistent with the results of Konecka et al. (2012), Mahalakshmi et al. (2012), Nemappa et al. (2012), Shishir et al. (2014), Constanski et al. (2015) and Soares da Silva et al. (2017) but divergent from those of Jouzani et al. (2008), Salekjalali et al. (2012), Khojand et al. (2013) and El-Kersh et al. (2014), who found these genes to be more frequent in Bt isolates. The low frequency of cryl genes in the evaluated isolates does not necessarily represent a limitation since these genes are toxic not only to dipterans but also to insects in Lepidoptera or Coleoptera (Silva et al., 2012; Jouzani et al., 2017).

The dissociation of the intestinal cells from each other, the irregularity of the microvilli and even the cell degeneration in the A. aegypti larval intestine after $6 \mathrm{~h}$ and $24 \mathrm{~h}$ prove the highly toxic action of the evaluated $\mathrm{Bt}$ isolates. This result is consistent with data from Rey et al. (1998) and Cavados et al. (2004) that identified these characteristics as determinants of the toxic action of $\mathrm{Bt}$ species and the subsequent death of the susceptible host. However, after $6 \mathrm{~h}$ of exposure, we still observed the initial toxic action of the BtMA-179 isolate in the intestine of A. aegypti larvae, and the high production of digestive vesicles observed suggests an attempt at defence by the insect against the bacterial action (Oliveira et al., 2009).

The alterations due to the toxic activity of the new $\mathrm{Bt}$ isolates from Maranhão were more extensive after $24 \mathrm{~h}$, with the intestinal epithelium showing loose and disrupted cells. Isolate BtMA-459 caused complete disintegration of the intestinal epithelium of $A$. aegypti larvae. This result was similar to that observed by Charles and Barjac (1981) and Lahkim-Tsror et al. (1983) for B. thuringiensis subsp. israelensis, demonstrating that the new isolates have the potential for future use in the control of $A$. aegypti larvae.

The probable synergy between the cry and cyt genes and their specificity against dipterans caused serious damage to the larval intestinal epithelium. However, isolates for which only one gene was detected caused epithelial damage comparable to that caused by isolates with a combination of $c r y$ and $c y t$ genes, which may have been due to the presence of unknown genes. This finding may prompt a search for new gene profiles that differ from those currently known to enable mosquito toxicity.

The new isolates of $B$. thuringiensis from Maranhão soil are promising for the biological control of $A$. aegypti larvae, which can be evidenced by changes in the intestinal epithelium of larvae caused by Cry and Cyt toxins, making these isolates highly toxic and enabling them to be safely used as a biotechnological tool for the manufacture of biological larvicides with different combinations of toxins from those currently used.

\section{Acknowledgements}

To teachers Dr. Manoel Victor Franco Lemos and Janete Aparecida Desidério of the Laboratory of Genetics of Bacteria and Applied Biotechnology of the Department of Applied Biology. To Agriculture Faculdade de Ciências Agrárias e Veterinárias, Campus de Jaboticabal, Universidade Estadual Paulista Julio de Mesquita Filho (UNESP). To Dr. Maria Helena N. L. Silva-Filha (IAM-FIOCRUZ) for the suggestions on the manuscript. To Programa de Pós-Graduação em Biodiversidade, Ambiente e Saúde (PPGBAS) of Universidade Estadual do Maranhão (CESC-UEMA).

This work was supported by Fundação de Amparo à Pesquisa e Desenvolvimento Científico do Maranhão (FAPEMA) for research funding, which made it possible to carry out the study.

\section{References}

APONTE, A., PENILLA, R.P., RODRÍGUEZ, A.D. and OCAMPO, C.B., 2019. Mechanisms of pyrethroid resistance in Aedes (Stegomyia) aegypti from Colombia. Acta Tropica, vol. 191, pp. 146-154. http://dx.doi.org/10.1016/j.actatropica.2018.12.021. PMid:30552882

BAIG, D. and MEHNAZ, S., 2010. Determination and distribution of cry-type genes in halophilc Bacillus thuringiensis isolates of Arabian Sea sedimentary rocks. Microbiological Research, vol. 165, no. 5, pp. 376-383. http://dx.doi.org/10.1016/j.micres.2009.08.003. PMid:19850456.

BASSANI, A.T., TRAMONTINA, A.C. and TRAMONTINA, F.F., 2019. Educação ambiental, vigilância em saúde e o controle do vetor Aedes aegypti (Linnaeus, 1762) (Diptera: culicidae. Revista Eletrônica do Mestrado em Educação Ambiental, vol. 36, no. 1, pp. 339-356.

BEN-DOV, E., 2014. Bacillus thuringiensis subsp. israelensis and its dipteran-specific toxins. Toxins, vol. 6, no. 4, pp. 12221243. http://dx.doi.org/10.3390/toxins6041222. PMid:24686769.

BEN-DOV, E., ZARITSKY, A., DAHAN, E., BARAK, Z., SINAI, R., MANASHEROB, R., KHAMRAEV, A., TROITSKAYA, E., DUBITSKY, A., BEREZINA, N. and MARGALITH, Y., 1997. Extended screening by PCR for seven cry-group genes from field-collected strains of Bacillus thuringiensis. Applied and Environmental Microbiology, vol. 63, no. 12, pp. 4883-4890. http:// dx.doi.org/10.1128/AEM.63.12.4883-4890.1997. PMid:9406409.

BOONSERM, P., DAVIS, P., ELLAR, D.J. and LI, J., 2005. Crystal structure of the mosquito-larvicidal toxin Cry4Ba and Its biological implications. Journal of Molecular Biology, vol. 348, no. 2, pp. 363-382. http://dx.doi.org/10.1016/j.jmb.2005.02.013. PMid:15811374.

BRAGA, I.A. and VALLE, D., 2007. Aedes aegypti: inseticidas, mecanismos de ação e resistência. Epidemiologia e Serviços de Saúde: Revista do Sistema Único de Saúde do Brasil, vol. 6, no. 4, pp. 279-293. http://dx.doi.org/10.5123/S1679-4974200700040000. 
BRASIL. Ministério da Saúde. Secretaria de Vigilância em Saúde, 2019 [viewed 18 August 2019]. Monitoramento dos casos de arboviroses urbanas transmitidas pelo Aedes (dengue, chikungunya e Zika) até a Semana Epidemiológica 12 de 2019 e Levantamento Rápido de Índices para Aedes aegypti (LIRAa) [online]. Brasília: Secretaria de Vigilância em Saúde. Boletim Epidemiológico, no. 50. Available from: http://portalsaude.saude.gov.br

BRAVO, A., LIKITVIVATANAVONG, S., GILL, S.S. and SOBERÓN, M., 2011. Bacillus thuringiensis: a story of a successful bioinsecticide. Insect Biochemistry and Molecular Biology, vol. 41, no. 7, pp. 423-431. http://dx.doi.org/10.1016/j. ibmb.2011.02.006. PMid:21376122.

BRAVO, A., SARABIA, S., LOPEZ, L., ONTIVEROS, H., ABARCA, C., ORTIZ, A., ORTIZ, M., LINA, L., VILLALOBOS, F.J., PENA, G., NUNEZ-VALDEZ, M.-E., SOBERON, M. and QUINTERO, R., 1998. Characterization of cry genes in a mexican Bacillus thuringiensis strain collection. Applied and Environmental Microbiology, vol. 64, no. 12, pp. 4965-4972. http:// dx.doi.org/10.1128/AEM.64.12.4965-4972.1998. PMid:9835590.

CARVALHO, F.D. and MOREIRA, L.A., 2017. Why is Aedes aegypti Linnaeus so successful as a species? Neotropical Entomology, vol. 46, no. 3, pp. 243-255. http://dx.doi.org/10.1007/ s13744-017-0520-4. PMid:28401481.

CAVADOS, C.F.G., MAJEROWICZ, S., CHAVES, J.Q., ARAÚJO-COUTINHO, C.J.P.C. and RABINOVITCH, L., 2004. Histopathological and ultrastructural effects of $\delta$-endotoxins of Bacillus thuringiensis serovar israelensis in the midgut of Simulium pertinax larvae (Diptera, Simuliidae). Memórias do Instituto Oswaldo Cruz, vol. 99, no. 5, pp. 493-498. http://dx.doi. org/10.1590/S0074-02762004000500006. PMid:15543412.

CHARLES, L.F. and BARJAC, H., 1981. Histopathologie de l'action de la $\delta$-endotoxine deBacillus thuringiensis var.Israelensis sur les larves d'Aedes aegypti (Dip.:Culicidae). Entomophaga, vol. 26, no. 2, pp. 203-212. http://dx.doi.org/10.1007/BF02375033.

CONSOLI, R.A.G.B. and LOURENÇO-DE-OLIVEIRA, R., 1994. Principais mosquitos de importância sanitária no Brasil. Rio de Janeiro: FIOCRUZ. http://dx.doi.org/10.7476/9788575412909.

CONSTANSKI, K.C., ZORZETTI, J., BOAS, G.T.V., RICIETO, A.P.S., FAZION, F.A.P., BOAS, L.V., MONNERAT, R.G. and NEVES, P.M.O.J., 2015. Seleção e caracterização molecular de isolados de Bacillus thuringiensis para o controle de Spodoptera spp. Pesquisa Agropecuária Brasileira, vol. 50, no. 8, pp. 730733. http://dx.doi.org/10.1590/S0100-204X2015000800012.

COSTA, J.R.V., ROSSI, J.R., MARUCCI, S.C., ALVES, E.C.C., VOLPE, H.X.L., FERRAUDO, S.S., LEMOS, M.V.F. and DESIDÉRIO, J., 2010. Atividade tóxica de isolados de Bacillus thuringiensis a larvas de Aedes aegypti (L.) (Diptera: culicidae). Neotropical Entomology, vol. 39, no. 5, pp. 757-766. http://dx.doi. org/10.1590/S1519-566X2010000500015. PMid:21120386.

CRICKMORE, N., 2017 [viewed 4 February 2017]. Full list of Delta-endotoxins [online]. Available from: http://www. btnomenclature.info/

CRICKMORE, N., BONE, E.J., WILLIAMS, J.A. and ELLAR, D.J., 1995. Contribution of the individual components of the $\delta$-endotoxin crystal to the mosquitocidal activity of Bacillus thuringiensis subsp israelensis. FEMS Microbiology Letters, vol. 131, no. 3, pp. 249-254. http://dx.doi.org/10.1016/03781097(95)00264-6.

EJIOFOR, A.O. and JOHNSON, T., 2002. Physiological and molecular detection of crystalliferous Bacillus thuringiensis strains from habitats in the South Central United States. Journal of Industrial Microbiology \& Biotechnology, vol. 28, no. 5, pp. 284-290. http://dx.doi.org/10.1038/sj.jim.7000244. PMid:11986933.
EL-KERSH, T.A., AL-AKEEL, R.A., AL-SHEIKH, Y.A. and ALHARBI, S.A., 2014. Isolation and distribution of mosquitolarvicidal cry genes in Bacillus thuringiensis strains native to Saudi Arabia. Tropical Biomedicine, vol. 31, no. 4, pp. 616-632. PMid:25776587.

GLARE, T.R. and O'Callagham, M., 2000. Bacillus thuringiensis: biology, ecology and safety. Chichester: John Wiley \& Sons.

GOLDBERG, L.J. and MARGALIT, J., 1977. A bacterial spore demonstrating rapid larvicidal activity against Anopheles sergentii, Uranotaenia unguiculata, Culex univitattus, Aedes aegypti and Culex pipiens. Mosquito News, vol. 37, no. 3, pp. 355-358.

HABIB, M.E.M., 1983. Potency of Bacillus thuringiensis var. israelensis (H14) against some aquatic dipterous insects. Zeitschrift für Angewandte Entomologie, vol. 95, no. 1-5, pp. 368-376. http:// dx.doi.org/10.1111/j.1439-0418.1983.tb02656.x.

IBARRA, J.E., DEL RINCÓN, M.C., ORDÚZ, S., NORIEGA, D., BENINTENDE, G., MONNERAT, R., REGIS, L., DE OLIVEIRA, C.M., LANZ, H., RODRIGUEZ, M.H., SÁNCHEZ, J., PEÑA, G. and BRAVO, A., 2003. Diversity of Bacillus thuringiensis strains from Latin America with insecticidal activity against different mosquito species. Applied and Environmental Microbiology, vol. 69, no. 9, pp. 5269-5274. http://dx.doi.org/10.1128/AEM.69.9.52695274.2003. PMid:12957913.

JOUZANI, G.S., ABAD, A.P., SEIFINEJAD, A., MARZBAN, R., KARIMAN, K. and MALEKI, B., 2008. Distribution and diversity of dipteran-specific cry and cyt genes in native Bacillus thuringiensis strains obtained from different ecosystems of Iran. Journal of Industrial Microbiology \& Biotechnology, vol. 35, no. 2, pp. 83-94. http://dx.doi.org/10.1007/s10295-007-0269-6. PMid: 17999100

JOUZANI, G.S., VALIJANIAN, E. and SHARAFI, R., 2017. Bacillus thuringiensis: a successful insecticide with new environmental features and tidings. Applied Microbiology and Biotechnology, vol. 101, no. 7, pp. 2691-2711. http://dx.doi.org/10.1007/s00253017-8175-y. PMid:28235989.

KHOJAND, S., KESHAVARZI, M., ZARGARI, K., ABDOLAHI, H. and ROUZBEH, F., 2013. Presence of multiple cry genes in Bacillus thuringiensis isolated from dead cotton bollworm Heliothis armigera. Journal of Agricultural Science and Technology, vol. 15 , no. 6 , pp. 1285-1292.

KONECKA, E., BARANEK, J., HRYCAK, A. and KAZNOWSKI, A., 2012. Insecticidal activity of Bacillus thuringiensis strains isolated from soil and water. TheScientificWorldJournal, vol. 2012, pp. 1-5. http://dx.doi.org/10.1100/2012/710501. PMid:22666145.

LACEY, L.A., 2007. Bacillus thuringiensis serovariety israelensis and Bacillus sphaericus for mosquito control. Journal of the American Mosquito Control Association, vol. 23, no. 2, suppl., pp. 133-163. http://dx.doi.org/10.2987/8756-971X(2007)23[13 3:BTSIAB]2.0.CO;2. PMid:17853604.

LAHKIM-TSROR, L., PASCAR-GLUZMAN, C., MARGALIT, J. and BARAK, Z., 1983. Larvicidal activity of Bacillus thuringiensis subsp. israelensis, serovar H14 in Aedes aegypti: histopathological studies. Journal of Invertebrate Pathology, vol. 41, no. 1, pp. 104-116. http://dx.doi.org/10.1016/0022-2011(83)90241-0. PMid:6841993.

LOBO, K.S., SOARES-DA-SILVA, J., SILVA, M.C., TADEI, W.P., POLANCZYK, R.A. and PINHEIRO, V.C.S., 2018. Isolation and molecular characterization of Bacillus thuringiensis found in soils of the Cerrado region of brazil, and their toxicity to Aedes aegypti larvae. Revista Brasileira de Entomologia, vol. 62, no. 1, pp. 5-12. http://dx.doi.org/10.1016/j.rbe.2017.11.004.

MAHALAKSHMI, A., SUJATHA, K., KANI, P. and SHENBAGARATHAI, R., 2012. Distribution of cry and cyt 
genes among Indigenous Bacillus thuringiensis isolates with mosquitocidal activity. Advances in Microbiology, vol. 2, no. 3, pp. 216-226. http://dx.doi.org/10.4236/aim.2012.23026.

MONTAGNER, F.R.G., SILVA, O.S. and JAHNKE, S.M., 2018. Mosquito species occurrence in association with landscape composition in green urban areas. Brazilian Journal of Biology = Revista Brasileira de Biologia, vol. 78, no. 2, pp. 233-239. http://dx.doi.org/10.1590/1519-6984.04416. PMid:28793030.

MOYES, C.L., VONTAS, J., MARTINS, A.J., NG, L.C., KOOU, S.Y., DUSFOUR, I., RAGHAVENDRA, K., PINTO, J., CORBEL, V., DAVID, J.-P. and WEETMAN, D., 2017. Contemporary status of insecticide resistance in the major Aedes vectors of arboviruses infecting humans. PLoS Neglected Tropical Diseases, vol. 11, no. 7, pp. e0005625. http://dx.doi.org/10.1371/journal.pntd.0005625. PMid:28727779.

NAZARIAN, A., JAHANGIRI, R., JOUZANI, G.S., SEIFINEJAD, A., SOHEILIVAND, S., BAGHERI, O., KESHAVARZI, M. and ALAMISAEID, K., 2009. Coleopteran specific and putative novel cry genes in Iranian native Bacillus thuringiensis collection. Journal of Invertebrate Pathology, vol. 102, no. 2, pp. 101-109. http://dx.doi.org/10.1016/j.jip.2009.07.009. PMid:19631215

NEMAPPA, L., UDAYASURIYAN, V., RAJESH, A.M., YATHISH, K.R., SWAMY, M.H.K. and SOMAPPA, J., 2012. Screening of new isolates of Bacillus thuringiensis $(\mathrm{Bt})$ and cloning of the cry genes. African Journal of Biotechnology, vol. 11, no. 75, pp. 13974-13979. http://dx.doi.org/10.5897/AJB12.2194.

OLIVEIRA, C.D., TADEI, W.P. and ABDALLA, F.C., 2009. Occurrence of apocrine secretion in the larval gut epithelial cells of Aedes aegypti L., Anopheles albitarsis Lynch-Arribálzaga and Culex quinquefasciatus say (Diptera: Culicidae): a defense strategy against infection by Bacillus sphaericus Neide?Neotropical Entomology, vol. 38, no. 5, pp. 624-631. http://dx.doi.org/10.1590/ S1519-566X2009000500010. PMid:19943010.

RAYMOND, B., JOHNSTON, P.R., NIELSEN-LEROUX, C., LERECLUS, D. and CRICKMORE, N., 2010. Bacillus thuringiensis: an impotent pathogen? Trends in Microbiology, vol. 18, no. 5, pp. 189-194. http://dx.doi.org/10.1016/j.tim.2010.02.006. PMid:20338765.

REY, D., LONG, A., PAUTOU, M.P. and MEYRAN, J.C., 1998. Comparative histopathology of some Diptera and Crustacea of aquatic alpine ecosystems, after treatment with Bacillus thuringiensis var. israelensis. Entomologia Experimentalis et Applicata, vol. 88, no. 3, pp. 255-263. http://dx.doi.org/10.1046/j.1570-7458.1998.00370.x.

SALEKJALALI, M., BARZEGARI, A. and JAFARI, B., 2012. Isolation, Pcr detection and diversity of native Bacillus thuringiensis strains collection isolated from diverse Arasbaran natural ecosystems. World Applied Sciences Journal, vol. 18, no. 8, pp. 1133-1138. http://dx.doi.org/10.5829/idosi.wasj.2012.18.08.1456.

SCHNEPF, E., CRICKMORE, N., VAN RIE, J., LERECLUS, D., BAUM, J., FEITELSON, J., ZEIGLER, D.R. and DEAN, D.H., 1998. Bacillus thuringiensis and its pesticidal crystal proteins. Microbiology and Molecular Biology Reviews, vol. 62, no. 3, pp. 775-806. http://dx.doi.org/10.1128/MMBR.62.3.775-806.1998. PMid:9729609.

SEIFINEJAD, A., JOUZANI, G.R.S., HOSSEINZADEH, A. and ABDMISHANI, C., 2008. Characterization of Lepidopteraactive cry and vip genes in Iranian Bacillus thuringiensis strain collection. Biological Control, vol. 44, no. 2, pp. 216-226. http:// dx.doi.org/10.1016/j.biocontrol.2007.09.010.

SHISHIR, A., ROY, A., ISLAM, N., RAHMAN, A., KHAN, S.N. and HOQ, M.M., 2014. Abundance and diversity of Bacillus thuringiensis in Bangladesh and their cry genes profile. Frontiers in Environmental Science, vol. 2, pp. 20. http://dx.doi.org/10.3389/ fenvs.2014.00020.

SILVA, M.C., SIQUEIRA, H.A.A., MARQUES, E.J., SILVA, L.M., BARROS, R., LIMA FILHO, J.V.M. and SILVA, S.M.F.A., 2012. Bacillus thuringiensis isolates from northeastern Brazil and their activities against Plutella xylostella (Lepidoptera: Plutellidae) and Spodoptera frugiperda (Lepidoptera: Noctuidae). Biocontrol Science and Technology, vol. 22, no. 5, pp. 583-599. http://dx.doi. org/10.1080/09583157.2012.670802.

SOARES-DA-SILVA, J., PINHEIRO, V.C.S., LITAIFF-ABREU, E., POLANCZYK, R.A. and TADEI, W.P., 2015. Isolation of Bacillus thuringiensis from the state of Amazonas, in Brazil, and screening against Aedes aegypti (Diptera, Culicidae). Revista Brasileira de Entomologia, vol. 59, no. 1, pp. 1-6. http://dx.doi. org/10.1016/j.rbe.2015.02.001

SOARES-DA-SILVA, J., QUEIRÓS, S.G., AGUIAR, J.S., VIANA, J.L., VIEIRA-NETA, M.R.A., SILVA, M.C., PINHEIRO, V.C.S., POLANCZYK, R.A., CARVALHO-ZILSE, G.A. and TADEI, W.P., 2017. Molecular characterization of the gene profile of Bacillus thuringiensis Berliner isolated from Brazilian ecosystems and showing pathogenic activity against mosquito larvae of medical importance. Acta Tropica, vol. 176, pp. 197-205. http://dx.doi. org/10.1016/j.actatropica.2017.08.006. PMid:28823909.

SOBERÓN, M., MONNERAT, R. and BRAVO, A., 2018. Mode of action of cry toxins from Bacillus thuringiensis and resistance mechanisms. Microbial Toxins, pp. 15-27. In press.

SUN, Y., ZHAO, Q., XIA, L., DING, X., HU, Q., FEDERICI, B.A. and PARK, H.W., 2013. Identification and characterization of three previously undescribed crystal proteins from Bacillus thuringiensis subsp. jegathesan. Applied and Environmental Microbiology, vol. 79, no. 11, pp. 3364-3370. http://dx.doi. org/10.1128/AEM.00078-13. PMid:23524673.

VALLE, D., PIMENTA, D.N. and AGUIAR, R., 2016. Zika, dengue e chikungunya: desafios e questões. Epidemiologia $e$ Serviços de Saúde: Revista do Sistema Único de Saúde do Brasil, vol. 25, no. 2, pp. 419-422. http://dx.doi.org/10.5123/S167949742016000200020. PMid:27869959.

VAN FRANKENHUYZEN, K., 2013. Cross-order and crossphylum activity of Bacillus thuringiensis pesticidal proteins. Journal of Invertebrate Pathology, vol. 114, no. 1, pp. 76-85. http://dx.doi.org/10.1016/j.jip.2013.05.010. PMid:23747826.

VASCONCELOS, P.F.C., 2015. Doença pelo vírus Zika: um novo problema emergente nas Américas? Revista Pan-Amazônica Saúde, vol. 6, no. 2, pp. 9-10. http://dx.doi.org/10.5123/S217662232015000200001

VIDAL-QUIST, J.C., CASTAÑERA, P. and GONZÁLEZCABRERA, J., 2009. Diversity of of Bacillus thuringiensis STRAINS ISOLATED FROM CITRUS ORCHARDs in Spain and evaluation of their insecticidal activity against Ceratitis capitata. Journal of Microbiology and Biotechnology, vol. 19, no. 8, pp. 749-759. PMid:19734711.

ZARA, A.L.D.S.A., SANTOS, S.M.D., FERNANDES-OLIVEIRA, E.S., CARVALHO, R.G. and COELHO, G.E., 2016. Estratégias de controle do Aedes aegypti: uma revisão. Epidemiologia e Serviços de Saúde: Revista do Sistema Único de Saúde do Brasil, vol. 25, no. 2, pp. 391-404. . PMid:27869956.

ZHANG, Q., HUA, G. and ADANG, M.J., 2017. Effects and mechanisms of Bacillus thuringiensis crystal toxins for mosquito larvae. Insect Science, vol. 24, no. 5, pp. 714-729. http://dx.doi. org/10.1111/1744-7917.12401. PMid:27628909. 